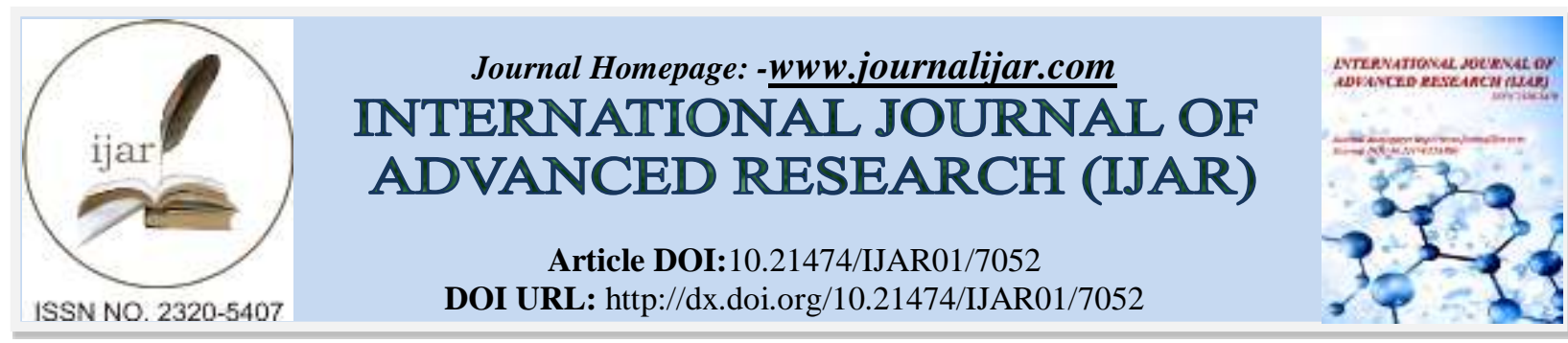

RESEARCH ARTICLE

\title{
THE NORMAL ANTHROPOMETRIC MEASUREMENTS FOR HEALTHY FULL TERM NEWBORNS IN NAJAF CITY.
}

Dr. Ali zgher hameed.

M.b.ch.b, d.c.h, babel health directorate.

\section{Manuscript Info}

Manuscript History

Received: 07 March 2018

Final Accepted: 09 April 2018

Published: May 2018

\section{Abstract}

Background:-Determination of newborn growth parameters is necessary in each population from different locations for planning their subsequent children growth charts and thus detecting disease by recognizing overt deviation from normal patterns.

Objectives:-To establish the normal anthropometric measurements ( $\mathrm{Wt}, \mathrm{L}, \mathrm{OFC}, \mathrm{CC}, \mathrm{MAC}$ and MTC) for appropriately grown full term newborns in Najaf city-Iraq.

Patients \& Method:- A study was carried out enrolling 500 singleton healthy full term neonates (268 males and 232 females), (325 urban and 175 rural), (166 primipara and 334 multipara), (290 VD and $210 \mathrm{CS}$ ), (205 regular ANC and 295 irregular ANC) who completed 37 weeks of gestation and were delivered in Al-Zahraa maternity and children teaching hospital during the period between 1st April to 30th of October 2010. The data and measurements were done during the 1st day of life with exclusion of newborns of mothers with high risk, complicated pregnancies and labors. The included measurements were Wt, L, OFC, CC, MAC and MTC. Wt was measured by electronic scale, $\mathrm{L}$ by hard plastic platform (stadiometer), other measurements by flexible non-stretchable plastic tape measure. The studied variables were gender, residence, parity of the mother, mode of delivery and antenatal care. The data analyzed by SPSS (version 17) program for mean, standard deviation, range, $\mathrm{p}$-value and correlation coefficient.

Results:- Males had a significantly higher $\mathrm{CC}$ than females with no significant difference in OFC, Wt, L, MAC and MTC. There was a highly significant difference in Wt between urban and rural neonates( Urban were higher). A significantly higher OFC in rural than urban neonates with no significant difference in L, CC, MAC and MTC. There was a highly significant difference in OFC between multipara and primipara women neonates (multipara were higher). Multipara women neonates were significantly higher in $\mathrm{Wt}$ than primipara women neonates. There was no significant difference in L, CC, MAC and MTC. There was no significant difference in OFC, Wt, L, CC, MAC and MTC regarding the mode of delivery whether it was VD or CS.A significantly higher OFC and $\mathrm{Wt}$ in neonates of mothers with irregular ANC than neonates of mothers with regular ANC.

Conclusions:-This study established local normal values for anthropometric measurements (Wt, L, OFC, CC, MAC and MTC) for 
healthy, full term newborn in Najaf city. There was a highly significant degree of correlation between all the studied measurements.

Copy Right, IJAR, 2018,. All rights reserved.

\section{Introduction:-}

Anthropometry is the measurement of physical dimensions of the human body at different ages ${ }^{[1]}$. Anthropometry is an effective and frequently performed child health and nutrition screening procedure. The value of physical growth data depends on their accuracy and reliability, how they are recorded and interpreted, and what follow up efforts are made after identification of growth abnormality ${ }^{[2]}$. Determination of birth indices is necessary in each population from different locations for planning their subsequent children growth chart ${ }^{[2]}$. Anthropometric measurements can assess growth cross-sectionally or longitudinally. If children are measured once, their growth status for age can be assessed by comparing this measurement with the appropriate reference chart, if children are measured more than once, growth velocity data are obtained that can be more valuable because they reflect changes in growth and development ${ }^{[3]}$. A detailed physical examination of every neonate is established as good practice and is required as part of the child health surveillance pro- gram in the United Kingdom, this examination should be performed by an appropriately trained doctor and there is no optimal timing for examination but generally carried out between six and 72 hours $^{[4]}$. A knowledge of the normal growth and development of children is essential for preventing and detecting disease by recognizing overt deviation from normal patterns ${ }^{[5]}$. There is a growing evidence supporting the roles of certain candidates genes in influencing size at birth ${ }^{[6]}$. Given a normal genetic endowment, a healthy well nourished mother, a normal pregnancy and delivery, the provision of appropriate nutrition and a supportive home and community environment, a child will grow and develop normally $^{[7]}$. Genetic difference exists among races regarding growth and body composition ${ }^{[8]}$. Infants of mothers of Asian origin are lighter and shorter than those of European and North American white mothers; this may be really the result of variation in maternal or other environmental factors ${ }^{[9]}$. The body shape, proportion, composition and metabolic rate of the fetus and infant differ from those of the fully grown adult, the fetus accretes calcium, phosphorus and iron in the last trimester although ossification of the fetal skeleton begins at a weight of 700-900 $\mathrm{gm}$, fat is laid down at weight over $2600 \mathrm{gm}$ and from birth the neonate continues to increase its fat stores until late infancy ${ }^{[10]}$. The normal pattern of growth in children is traditionally described in an up to date ethnic specific growth charts, growth references are valuable tools for accessing the health of individuals and for health planner to assess the wellbeing of populations ${ }^{[11]}$. In May 2000 the United states center for disease control (CDC) released growth charts, which are based on five nationally representative surveys conducted between 1963 and $1994^{[12]}$. In April 2006 the WHO released new standards for assessing the growth and development of children from birth to five years of age ${ }^{[13]}$. The WHO child growth standards are the product of a systematic process initiated in the early 1990s involving various reviews of the uses of anthropometric references and alternative approaches to developing new tools to assess growth ${ }^{[14]}$. In an effort to set an internationally usable standard for optimal growth in young children, the WHO is conducting the Multicenter growth reference study (MGRS) to develop growth curves that can be used for assessing early growth among children from around the world ${ }^{[15]}$.The NCHS data are representative of a population of well nourished and healthy children in the united states. Although this population is dissimilar to much of the rest of the world, the NCHS charts have been accepted by the world organization as the international standard of growth for the first 5 years of life ${ }^{[16]}$. The ideal is to establish local national growth chart reflecting each country own genetic characteristics and prepared according to the features outlined by WHO. The first standard WHO advises for the growth indexes is that population chosen should be composed of "normal" children who have good nutritional status and grow in "optimal" conditions ${ }^{[17]}$. The percentile is the percentage of individuals in the group who have achieved a certain measured quantity, for anthropometric data ,the percentile cutoffs can be calculated from the mean and standard deviation. The 5th, 10 th and 25 th percentile correspond to -1.6 standard deviation , -1.3 standard deviation and -0.7 standard deviation respectively ${ }^{[18]}$. Normal growth customarily falls between the 10th and 90th percentile when plotted on growth chart to facilitate comparison to established norms, this can help to identify special needs ${ }^{[19]}$. Several factors were found to have an effect on a way or another on these measurements. These factors were investigated by numerous studies in different countries. They were classified as epidemiological and medical factors. The epidemiological factors are: sex of the baby, age of the mother, social class, education, ethnicity, race and occupation of the mother. Medical factors include maternal diseases (hypertension, diabetes mellitus, urinary tract infection), twining, under nutrition and smoking ${ }^{[9]}$. Based on their history,10-20\% of pregnant women can be identified as high risk; nearly half of all perinatal mortality and morbidity is associated with these pregnancies. High risk pregnancies are those that increase 
the likelihood of abortion, fetal death, IUGR, poor cardiopulmonary or metabolic transitioning at birth, fetal or neonatal disease, or other handicaps ${ }^{[20]}$. The neonatal period is a highly vulnerable time for an infant. The high neonatal morbidity and mortality rates attest to the fragility of life during this period; in the united states, of all deaths occurring in the first year, two thirds are in the neonatal period ${ }^{[21]}$. Careful surveillance of the obstetric patient is directed toward the identification of developing problems that may affect the fetus or mother adversely ${ }^{[22]}$. Improving the quality of obstetric care is an urgent priority in developing countries, where maternal mortality remains high ${ }^{[23]}$. Absent or delayed onset of prenatal care is associated with increased rate of IUGR infant. However, prenatal care does provide the opportunity to detect (and possibly treat) some of maternal and fetal conditions which can lead to IUGR ${ }^{[24]}$. ANC is considered regular if first visit is in the first or second trimester or number of visits 4-5 during the whole pregnancy ${ }^{[25]}$. Mothers in deprived socioeconomic conditions frequently have growth retarded infant. In those setting, primarily from the mothers poor nutrition and health over a long period of time, including during pregnancy, the high prevalence of specific and non specific infections, or from pregnancy complications underpinned by poverty ${ }^{[26]}$. Some studies indicate fatigue during work or upright posture might diminish uterine blood flow and thus hinder the supply of oxygen and nutrient to the fetus ${ }^{\text {[27] }}$. Maternal parity exert a modest effect on birth, first born infant tend to be smaller and often categorized as IUGR. This effect decreases with successive deliveries and less likely to be seen beyond the third birth ${ }^{[28]}$. Women ,whose $1^{\text {st }}$ pregnancy result in growth restricted infant, have been regarded to be with 1 in 4 risk of delivering a second infant below the 10th percentile, while after two pregnancies complicated by IUGR with four fold increase in the risk of subsequent growth restricted infant ${ }^{[29]}$. The incidence of LBW in teenagers nilliparus are higher ${ }^{[30]}$.Also, increase in maternal age (> 35 years) show increase incidence of LBW compared with younger age ${ }^{[31]}$. Advanced maternal age increases the risk of both chromosomal and non chromosomal fetal malformations ${ }^{[20]}$. Older women also have more unintended pregnancies -itself is a risk factor for low birth weight- than do women in their twenties and early thirties ${ }^{[32]}$. Maternal infections increase the risk of delivery of LBW ${ }^{[33]}$. The average term newborn weighs approximately $3.4 \mathrm{Kg}$, boys are slightly heavier than girls, the average length and head circumference are about $50 \mathrm{~cm}$ and $35 \mathrm{~cm}$ respectively, in term infants ${ }^{[34]}$. The birth weight of a newborn is a significant determinant of neonatal and postnatal infant mortality ${ }^{[35]}$. The birth weight is potentially a useful parameter for measurement of health during the vulnerable periods of life and serves as a useful indicator of health of the community because it is sensitive to environmental and socioeconomic influences ${ }^{[36]}$. Body length tends to be a better gauge of gestational age than body weight in under grown neonates with chromosomal abnormalities or congenital Rubella ${ }^{[37]}$. Growth in length reflects the differential growth of the head, trunk, and long bones of the legs . Head size increases most rapidly after 28 weeks of gestation, and growth slows before 2-3 years of life .The trunk increases during the same period but continues to lengthen at a slower rate from 2 years through puberty. The legs grow fastest during the period covering the last 14 weeks of gestation through the first $6 \mathrm{months}$ of life $(18 \mathrm{~cm} /$ $\mathrm{yr})$. This rate far exceeds that of leg growth in male puberty $(4 \mathrm{~cm} / \mathrm{yr})^{[38]}$. Head size attracts particular attention in infancy, the occipitofrontal circumference of the skull is measured soon after birth, not only to ensure that the baby does not have microcephaly, reflecting poor brain growth in utero, but also to establish a baseline for the first year of life.The head of the newborn infant makes up almost one third of total size compared with the adult proportion of approximately $1: 7^{[39]}$. The head circumference of the full term newborn is about $(2-3 \mathrm{~cm}) 1$ inch greater than the chest circumference which average $(30.5-33 \mathrm{~cm}) 12-13$ inch. ${ }^{[40]}$ Normally at birth, head circumference is larger than chest circumference. By the age of four months, the head circumference equals the chest circumference, and later the chest circumference is larger than head circumference except in the presence of malnutrition ${ }^{[41]}$. Mid-arm circumference is a good indicator of muscle bulk and is very useful in following children with malnutrition on treatment, combined with measurement of skin fold thickness (which measures fat) mid-arm circumference may help determine the proportion of fat to muscle ${ }^{[41]}$. Several studies have led to the conclusion that the newborns nutritional status is more important than birth weight alone for identifying perinatal risk ${ }^{[42,43]}$. Perinatal risk assessment by weight percentile criteria has been shown to be insufficient, thus requiring the determination of additional or alter- native indices to improve this evaluation ${ }^{[44,45]}$. Significant variation exists in mid-arm circumference and mid-thigh circumference values among different populations, these differences may be due to several factors, including genetic characteristics and nutritional status, as well as possible difference in measurements procedures ${ }^{[46]}$. The periodic measurement of anthropometric variables in different population and regions of a country reflect changes in children nutrition and health status and are a reliable tool to evaluate social health ${ }^{[47]}$. The main advantages of the measurements described above are practical, simple, non invasive, inexpensive, portable and highly suitable for pediatric use in the ward, clinic or community ${ }^{[48]}$. 


\section{Aim Of The Study:-}

1. To determine the normal standards of anthropometric measurements (birth weight, length, head circumference, chest circumference, mid-arm circumference and mid-thigh circumference) for full term neonates in Najaf city.

2. To compare the above measurements with some national and international studies.

3. To design charts that might be used as a base line for further related studies.

4. To identify an anthropometric surrogate to birth weight during the first 24 hours of life.

\section{Patients And Methods:-}

Five hundred normal singleton full term neonates (268 males and 232 females), (325 urban and 175 rural), (166 primipara and 334 multipara), (290 VD and 210 CS), (205 regular ANC and 295 irregular ANC) who completed 37 weeks of gestation and were delivered in Al-Zahraa maternity and children teaching hospital at Al-Najaf city - Iraq during the period between 1st April to 30th of October 2010.

The exclusion criteria include:

1. Neonates of high risk or complicated pregnancies by medical illness as hypertension, diabetes mellitus, infection, autoimmune disease, heart disease and smoking.

2. Neonates with visible congenital anomalies.

3. Neonates who had caput succedaneum and cephalhematoma.

4. Neonates who were delivered before 37 weeks of gestation.

The above four criteria were excluded by history and clinical examination, the data collection were taken by direct interview with the mothers and measurements were taken for their newborns by the researcher during the first 24 hours of life.

The studied variables were gender, residence (urban and rural), parity of the mother (primipara and multipara), mode of delivery (vaginal delivery and caesarean section), ANC (regular and irregular).

The studied measurements included: Wt, L,OFC,CC, MAC and MTC.

The Wt was measured in kilograms on naked neonates by an accurate electronic scale (SECA, Germany made, maximum Wt was $16 \mathrm{~kg}$ ).

A stadiometer (SECA, Germany made, maximum length was $99 \mathrm{~cm}$ ) is a hard plastic platform was used for measuring the $\mathrm{L}$ in centimeters by laying the baby supine on it with fully extended lower limbs, straight back and feet together with a head board placed against the baby's head and a movable foot board was pressed gently against the feet.

The OFC was determined in centimeters by using a flexible, non stretchable plastic tape measure ( Butterfly brand, China made) which was run one inch above the glabella to the occipital prominence, 3 measurements obtained and their mean was recorded.

The CC was determined at the level of nipples by a flexible, non stretchable tape measure during inspiration.

The MAC was measured over the left triceps muscle in a point midway between the tip of the acromian process and the tip of olecranon process, with the arm hanging on the side of the body. The MTC was measured by putting the baby on his right side and measure the circumference on the point over the left quadriceps muscle midway between the hip and knee joints.Regarding parity, a primipara is a woman who has been delivered only once of a fetus or fetuses born alive or dead with an estimated length of gestation of 20 weeks or more, multipara is a woman who has completed 2 or more pregnancies to 20 weeks or more ${ }^{[52]}$. The ANC was considered regular if first visit is in the first or second trimester, or number of visits 4-5 during the whole pregnancy. ${ }^{[24]}$ The gestational age included in this study (37- 41 completed weeks) was determined by last menstrual period, early ultrasound and the new Ballard score system (for both physical and neuromuscular criteria).The data processing was done using the statistical package for the social sciences SPSS (version 17).

Statistical analyses were performed to estimate the arithmetic mean, range, standard deviation and p-value.A significant statistical difference of variables was considered when $\mathrm{p}$-value $\leq 0.05$. The 2-tailed $\mathrm{t}$-test was used to compare all variables. A correlation matrix was built in order to test associations between the studied measurements. The curves were drawn by using Microsoft office Excel and Microsoft office Word 2007. 


\section{Results:-}

A total number of (500) healthy full term neonates were examined during the first day of life for Wt $(\mathrm{kg}), \mathrm{L}(\mathrm{cm})$, OFC $(\mathrm{cm}), \mathrm{CC}(\mathrm{cm}), \operatorname{MAC}(\mathrm{cm})$ and $\mathrm{MTC}(\mathrm{cm})$.

The male neonates were (268) (53.6\%), while the female neonates were (232) (46.4\%) given a male : female ratio of 1.15:1.

Table1:-The mean, standard deviation and p-value of measurements in relation to gender.

\begin{tabular}{|c|c|c|c|}
\hline Measurements & Males(268) & Females(232) & p-value \\
\hline OFC $(\mathrm{cm})$ & $34.42 \pm 1.03$ & $34.22 \pm 1.00$ & 0.78 \\
\hline $\mathrm{Wt}(\mathrm{kg})$ & $3.25 \pm 0.44$ & $3.15 \pm 0.47$ & 0.15 \\
\hline $\mathrm{L}(\mathrm{cm})$ & $49.94 \pm 1.64$ & $49.63 \pm 1.84$ & 0.64 \\
\hline CC $(\mathrm{cm})$ & $32.77 \pm 2.54$ & $32.35 \pm 1.41$ & $0.005^{*}$ \\
\hline MAC $(\mathrm{cm})$ & $11.21 \pm 1.08$ & $11.18 \pm 1.10$ & 0.22 \\
\hline MTC $(\mathrm{cm})$ & $13.79 \pm 1.25$ & $13.64 \pm 1.28$ & 0.39 \\
\hline
\end{tabular}

$*$ p-value is statistically different $(\leq 0.05)$.

The OFC for boys was $34.42 \pm 1.03 \mathrm{~cm}$, while for girls it was $34.22 \pm 1.00 \mathrm{~cm}$, with a non-significant difference between males and females (p-value > 0.05). For birth $\mathrm{Wt}$ of boys it was $3.25 \pm 0.44 \mathrm{~kg}$, while for girls it was $3.15 \pm 0.47 \mathrm{~kg}$, with no significant difference (p-value >0.05). Regarding $\mathrm{L}$ it was $49.94 \pm 1.64 \mathrm{~cm}$ for males and $49.63 \pm 1.84 \mathrm{~cm}$ for females, with no significant difference(p-value >0.05). The $\mathrm{CC}$ was $32.77 \pm 2.54 \mathrm{~cm}$ and $32.35 \pm 1.41 \mathrm{~cm}$ for males and females respectively with significantly higher CC in males than in females(p-value < $0.05)$. Regarding MAC, for boys it was $11.21 \pm 1.08 \mathrm{~cm}$, while for girls it was $11.18 \pm 1.10 \mathrm{~cm}$ with a non-significant difference in MAC between girls and boys(p-value > 0.05). The MTC was $13.79 \pm 1.25 \mathrm{~cm}$ for boys and $13.64 \pm 1.28$ $\mathrm{cm}$ for girls with no significant difference ( $\mathrm{p}$-value $>0.05$ ). Regarding residency, Urban neonates were (325), (65\%) and Rural neonates were (175), (35\%).

Table 2:-The mean, standard deviation and p-value of measurements according to residence (urban and rural).

\begin{tabular}{|c|c|c|c|}
\hline Measurements & Urban $(325)$ & Rural $(175)$ & p-value \\
\hline OFC $(\mathrm{cm})$ & $34.27 \pm 0.97$ & $34.44 \pm 1.10$ & $0.04^{*}$ \\
\hline Wt $(\mathrm{kg})$ & $3.21 \pm 0.41$ & $3.19 \pm 0.53$ & $0.00^{*}$ \\
\hline $\mathrm{L}(\mathrm{cm})$ & $49.77 \pm 1.75$ & $49.85 \pm 1.74$ & 0.10 \\
\hline CC(cm) & $32.55 \pm 1.99$ & $32.62 \pm 2.29$ & 0.50 \\
\hline MAC(cm) & $11.21 \pm 1.08$ & $11.16 \pm 1.11$ & 0.93 \\
\hline MTC(cm) & $13.73 \pm 1.25$ & $13.72 \pm 1.30$ & 0.24 \\
\hline
\end{tabular}

* p-value is statistically different $(\leq 0.05)$.

The OFC was $34.27 \pm 0.97 \mathrm{~cm}$ for urban group, while it was $34.44 \pm 1.10 \mathrm{~cm}$ for the rural group with a statistically significant difference (p-value < 0.05), Rural higher than Urban. The birth Wt of urban neonates was $3.21 \pm 0.41 \mathrm{~kg}$, while that of rural neonates was $3.19 \pm 0.53 \mathrm{~kg}$, with a statistically highly significant difference (p-value $<0.001$ ), Urban higher than Rural. The L for urban group was $49.77 \pm 1.75 \mathrm{~cm}$, while for rural group it was $49.85 \pm 1.74 \mathrm{~cm}$ with a non-significant difference ( $\mathrm{p}$-value > 0.05). Regarding CC for urban neonates it was $32.55 \pm 1.99 \mathrm{~cm}$ and that of rural one was $32.62 \pm 2.29 \mathrm{~cm}$, with a non-significant difference (p-value > 0.05). Regarding MAC, it was $11.21 \pm 1.08 \mathrm{~cm}$ and $11.16 \pm 1.11 \mathrm{~cm}$ for urban and rural group respectively, with no significant difference $(\mathrm{p}$-value $>$ 0.05 ). Birth MTC was $13.73 \pm 1.25 \mathrm{~cm}$ and $13.72 \pm 1.30 \mathrm{~cm}$ for urban and rural neonates respectively, with a nonsignificant difference (p-value > 0.05). Regarding parity, neonates of primipara mothers were (166), (33.2\%) and neonates of multimipara mothers were (334), (66.8\%).

Table 3:-The mean, standard deviation and p-value of measurements according to parity(primipara and multipara).

\begin{tabular}{|c|c|c|c|}
\hline Measurements & Primipara(166) & Multipara (334) & p-value \\
\hline OFC $(\mathrm{cm})$ & $34.18 \pm 0.88$ & $34.41 \pm 1.08$ & $0.000^{*}$ \\
\hline $\mathrm{Wt}(\mathrm{kg})$ & $3.17 \pm 0.42$ & $3.22 \pm 0.47$ & $0.008^{*}$ \\
\hline $\mathrm{L}(\mathrm{cm})$ & $49.59 \pm 1.91$ & $49.90 \pm 1.65$ & 0.242 \\
\hline $\mathrm{CC}(\mathrm{cm})$ & $32.45 \pm 2.68$ & $32.64 \pm 1.74$ & 0.193 \\
\hline MAC(cm) & $11.12 \pm 1.12$ & $11.23 \pm 1.8$ & 0.914 \\
\hline
\end{tabular}




\begin{tabular}{|c|c|c|c|}
\hline MTC $(\mathrm{cm})$ & $13.63 \pm 1.34$ & $13.77 \pm 1.22$ & 0.062 \\
\hline *p-value is statistically different $(\leq 0.05)$.
\end{tabular}

The OFC for newborns of primipara mothers was $34.18 \pm 0.88 \mathrm{~cm}$ and it was $34.41 \pm 1.08 \mathrm{~cm}$ for the newborns of multipara mothers with a highly significant difference between them ( $\mathrm{p}$-value $<0.001$ ), It was higher in multipara. The birth Wt for the newborns of primipara mothers was $3.17 \pm 0.42 \mathrm{~kg}$, which was significantly less than that of newborns of multipara mothers which was $3.22 \pm 0.47 \mathrm{~kg}$. Regarding L, there was no significant difference (p-value > 0.05 ) between the newborns of primipara mothers which was $49.59 \pm 1.91 \mathrm{~cm}$ and those of multipara mothers which was it was $49.90 \pm 1.65 \mathrm{~cm}$. The results of CC, MAC and MTC for the newborns of primipara mothers were $32.45 \pm 2.68 \mathrm{~cm}, 11.12 \pm 1.12 \mathrm{~cm}$ and $13.63 \pm 1.34 \mathrm{~cm}$, respectively, while for the newborns of multipara mothers the $\mathrm{CC}$ was $32.64 \pm 1.74 \mathrm{~cm}$, the MAC was $11.23 \pm 1.8 \mathrm{~cm}$ and the MTC was $13.77 \pm 1.22 \mathrm{~cm}$, with no significant difference between the results. Regarding the mode of delivery, VD neonates were (290), (58\%) and CS neonates were (210), (42\%).

Table 4:-The mean, standard deviation and $\mathrm{p}$ - value of the studied measurements in relation to the mode of delivery ( vaginal and caesarean section).

\begin{tabular}{|c|c|c|c|}
\hline Measurements & VD $(290)$ & CS $(210)$ & -value \\
\hline OFC $(\mathrm{cm})$ & $34.39 \pm 1.00$ & $34.25 \pm 1.06$ & 0.328 \\
\hline $\mathrm{Wt}(\mathrm{kg})$ & $3.26 \pm 0.46$ & $3.13 \pm 0.45$ & 0.657 \\
\hline $\mathrm{L}(\mathrm{cm})$ & $49.70 \pm 1.87$ & $49.94 \pm 1.54$ & 0.128 \\
\hline $\mathrm{CC}(\mathrm{cm})$ & $32.56 \pm 1.93$ & $32.60 \pm 2.31$ & 0.535 \\
\hline MAC $(\mathrm{cm})$ & $11.24 \pm 1.11$ & $11.14 \pm 1.06$ & 0.116 \\
\hline MTC $(\mathrm{cm})$ & $13.79 \pm 1.31$ & $13.64 \pm 1.20$ & 0.080 \\
\hline
\end{tabular}

The OFC was $34.39 \pm 1.00 \mathrm{~cm}$ for the vaginal delivery products and it was $34.25 \pm 1.06 \mathrm{~cm}$ for the caesarean section products. With no significant difference between them. The birth Wt of vaginal delivery products was $3.26 \pm 0.46 \mathrm{~kg}$, while that of caesarean section products was $3.13 \pm 0.45 \mathrm{~kg}$. With no significant difference between them. Regarding $\mathrm{L}$, it was $49.70 \pm 1.87 \mathrm{~cm}$ and $49.94 \pm 1.54 \mathrm{~cm}$ for the vaginal delivery and caesarean section products, respectively. With no significant difference between them. The $\mathrm{CC}$ for the vaginal delivery products was $32.56 \pm 1.93 \mathrm{~cm}$, while it was $32.60 \pm 2.31 \mathrm{~cm}$ for the other group. With no significant difference between them. The MAC and MTC for vaginal delivery products were $11.24 \pm 1.11 \mathrm{~cm}$ and $13.79 \pm 1.31 \mathrm{~cm}$ respectively, while the MAC for the caesarean section products was $11.14 \pm 1.06 \mathrm{~cm}$ and the MTC was $13.64 \pm 1.20 \mathrm{~cm}$. With no significant difference between them. According to regularity of ANC, neonates of regular ANC were (205), (41\%), and those of irregular ANC were (295), (59\%).

Table 5:-The mean, standard deviation and p-value according to the regularity of the ANC.

\begin{tabular}{|c|c|c|c|}
\hline Measurements & Regular ANC $(205)$ & Irregular ANC $(295)$ & p-value \\
\hline OFC $(\mathrm{cm})$ & $34.32 \pm 0.94$ & $34.34 \pm 1.08$ & $0.031^{*}$ \\
\hline $\mathrm{Wt}(\mathrm{kg})$ & $3.19 \pm 0.41$ & $3.21 \pm 0.49$ & $0.004^{*}$ \\
\hline $\mathrm{L}(\mathrm{cm})$ & $49.67 \pm 1.93$ & $49.89 \pm 1.59$ & 0.890 \\
\hline $\mathrm{CC}(\mathrm{cm})$ & $32.49 \pm 2.11$ & $32.64 \pm 2.09$ & 0.909 \\
\hline MAC $(\mathrm{cm})$ & $11.10 \pm 1.08$ & $11.26 \pm 1.10$ & 0.415 \\
\hline MTC $(\mathrm{cm})$ & $13.67 \pm 1.29$ & $13.76 \pm 1.25$ & 0.525 \\
\hline
\end{tabular}

$*$ p-value is statistically different $(\leq 0.05)$.

The newborns of mothers who had irregular ANC were heavier and had a larger OFC than those of mothers with regular ANC (p-value < 0.05), while all other measurements (L, CC, MAC and MTC) showed no significant difference. Regarding OFC, it was $34.32 \pm 0.94 \mathrm{~cm}$ for the regular ANC products, while it was $34.34 \pm 1.08 \mathrm{~cm}$ for the irregular ANC group. The birth Wt of those with regular ANC group was $3.19 \pm 0.41 \mathrm{~kg}$, while it was $3.21 \pm 0.49$ $\mathrm{kg}$ for the newborns of mothers with irregular ANC. The L for those with regular ANC was $49.67 \pm 1.93 \mathrm{~cm}$, while for the other group it was $49.89 \pm 1.59 \mathrm{~cm}$. The CC for the regular ANC group was $32.49 \pm 2.11 \mathrm{~cm}$ and it was $32.64 \pm 2.09 \mathrm{~cm}$ for the other group. The MAC and MTC for the regular ANC group were $11.10 \pm 1.08 \mathrm{~cm}$ and $13.67 \pm 1.29 \mathrm{~cm}$ respectively, while for the irregular ANC group the MAC was $11.26 \pm 1.10 \mathrm{~cm}$ and the MTC was $13.76 \pm 1.25 \mathrm{~cm}$. 
Table 6:- The percentiles (5th,10th,25th,50th,75th,90th and 95th) of all the studied measurements in relation to gender.

\begin{tabular}{|c|c|c|c|c|c|c|c|c|}
\hline \multirow[t]{2}{*}{ Measurements } & \multirow[t]{2}{*}{ Gender } & \multicolumn{7}{|c|}{ Percentiles } \\
\hline & & $5^{\text {th }}$ & $10^{\text {th }}$ & $25^{\text {th }}$ & $50^{\text {th }}$ & $75^{\text {th }}$ & $90^{\text {th }}$ & $95^{\text {th }}$ \\
\hline \multirow[t]{2}{*}{$\mathrm{OFC}(\mathrm{cm})$} & male & 33 & 33 & 34 & 34.5 & 35 & 36 & 36 \\
\hline & female & 33 & 33 & 33 & 34 & 35 & 35.5 & 36 \\
\hline \multirow[t]{2}{*}{$\mathrm{Wt}(\mathrm{kg})$} & male & 2.5 & 2.695 & 2.962 & 3.3 & 3.5 & 3.8 & 4 \\
\hline & female & 2.432 & 2.6 & 2.8 & 3.1 & 3.5 & 3.8 & 4 \\
\hline \multirow[t]{2}{*}{$\mathrm{L}(\mathrm{cm})$} & male & 47 & 48 & 49 & 50 & 51 & 52 & 52 \\
\hline & female & 47 & 48 & 49 & 50 & 51 & 51 & 52 \\
\hline \multirow[t]{2}{*}{$\mathrm{CC}(\mathrm{cm})$} & male & 30 & 30 & 32 & 33 & 34 & 35 & 35 \\
\hline & female & 30 & 30.15 & 31 & 32 & 33 & 34 & 35 \\
\hline \multirow[t]{2}{*}{$\mathrm{MAC}(\mathrm{cm})$} & male & 9 & 10 & 10.5 & 11 & 12 & 13 & 13 \\
\hline & female & 9 & 10 & 10 & 11 & 12 & 13 & 13 \\
\hline \multirow[t]{2}{*}{ MTC(cm) } & male & 12 & 12 & 13 & 14 & 15 & 15.05 & 16 \\
\hline & female & 12 & 12 & 13 & 13 & 15 & 15.5 & 16 \\
\hline
\end{tabular}

The OFC percentiles of boys (5th, 10th, 25th, 50th,75th,90th and 95th) were 33, 33, 34, 34.5, 35, 36 and $36 \mathrm{~cm}$ while that of girls were 33, 33, 33, 34, $35,35.5$ and $36 \mathrm{~cm}$, respectively. It shows a higher 25th, 50th, 90th percentiles in males than females while the remainder percentiles were equal in both. The Wt percentiles of boys (5th, 10th, 25th, 50th,75th,90th and 95th) were 2.5, 2.695, 2.962, 3.3, 3.5, 3.8 and $4 \mathrm{~kg}$, while that of girls were 2.432, 2.6, 2.8, 3.1, 3.5, 3.8 and $4 \mathrm{~kg}$, respectively. These values show a higher boys 5th,10th, 25th and 50th percentiles than the girls and an equal 75th, 90th and 95th percentiles for both. Regarding L percentiles of males (5th, 10th, 25th, 50th, 75th, 90th and 95th) ,they were 47, 48, 49, 50, 51, 52 and $52 \mathrm{~cm}$, while that of females were 47, 48, 49, 50, 51, 51 and $52 \mathrm{~cm}$, respectively. It was clear that the 90th percentile value was higher in males, while the remainder percentile values were equal in both. The CC percentiles of boys (5th, 10th, 25th, 50th, 75th, 90th and 95th) were $30,30,32,33,34,35$ and $35 \mathrm{~cm}$, while that of girls were $30,30.15,31,32,33,34$ and 35 cm respectively. It was apparent that the boys has a higher $25 \mathrm{th}, 50 \mathrm{th}, 75 \mathrm{th}$ and 90th percentiles than girls, while the girls were higher at the 10th percentile and the remainder were equal in both. Regarding the MAC percentiles $(5$ th, 10th,25th,50th,75th,90th and 95th)for boys were 9, 10,10.5,11, 12, 13 and $13 \mathrm{~cm}$, while for girls were 9, 10, 10,11, 12, 13 and $13 \mathrm{~cm}$ respectively. So the males were higher in the 25 th percentile and the remaining percentile values were equal in both. The MTC percentiles (5th, 10th, 25th, 50th, 75th, 90th and 95th) were 12, 12, 13, 14, 15, 15.05 and $16 \mathrm{~cm}$ for boys, while for girls were $12,12,13,13,15,15.5$ and $16 \mathrm{~cm}$ respectively. With a higher 50th percentile in males, and higher 90 th percentile in females, and the remainder percentiles were equal in both.

Table 7:-Pearson correlation coefficients for all included measurements.

\begin{tabular}{|c|c|c|c|c|c|c|c|}
\hline \multicolumn{2}{|c|}{ Measurements } & \multirow{2}{*}{$\begin{array}{c}\begin{array}{c}\mathrm{OFC} \\
(\mathrm{cm})\end{array} \\
1\end{array}$} & \multirow{2}{*}{$\begin{array}{c}\text { Weight } \\
(\mathrm{kg}) \\
.491^{\text {** }}\end{array}$} & \multirow{2}{*}{$\begin{array}{c}\text { Length } \\
(\mathrm{cm})\end{array}$} & \multirow{2}{*}{$\begin{array}{c}\mathrm{CC} \\
(\mathrm{cm}) \\
.426^{* * *}\end{array}$} & \multirow{2}{*}{$\begin{array}{l}\text { MAC } \\
(\mathrm{cm}) \\
.328^{* *}\end{array}$} & \multirow{2}{*}{$\begin{array}{l}\text { MTC } \\
(\mathrm{cm}) \\
.418^{* * *}\end{array}$} \\
\hline $\mathrm{OFC}(\mathrm{cm})$ & $\begin{array}{c}\text { Pearson } \\
\text { Correlation }\end{array}$ & & & & & & \\
\hline & Sig. (2-tailed) & & .000 & .000 & .000 & .000 & .000 \\
\hline \multirow[t]{2}{*}{ Weight $(\mathrm{kg})$} & $\begin{array}{c}\text { Pearson } \\
\text { Correlation }\end{array}$ & $.491^{* * *}$ & 1 & $.339^{* * *}$ & $.429^{* * *}$ & $.597^{* * *}$ & $.671^{* * *}$ \\
\hline & Sig. (2-tailed) & .000 & & .000 & .000 & .000 & .000 \\
\hline \multirow[t]{2}{*}{ Length $(\mathrm{cm})$} & $\begin{array}{c}\text { Pearson } \\
\text { Correlation }\end{array}$ & $.280^{* * *}$ & $.339^{* * *}$ & 1 & $.264^{* * *}$ & $.272^{* * \%}$ & $.229^{* * \pi}$ \\
\hline & Sig. (2-tailed) & .000 & .000 & & .000 & .000 & .000 \\
\hline \multirow[t]{2}{*}{$\mathrm{CC}(\mathrm{cm})$} & $\begin{array}{c}\text { Pearson } \\
\text { Correlation }\end{array}$ & $.426^{* *}$ & $.429^{\text {*** }}$ & $.264^{* *}$ & 1 & $.312^{* * *}$ & $.377^{* *}$ \\
\hline & Sig. (2-tailed) & .000 & .000 & .000 & & .000 & .000 \\
\hline \multirow[t]{2}{*}{$\mathrm{MAC}(\mathrm{cm})$} & $\begin{array}{c}\text { Pearson } \\
\text { Correlation }\end{array}$ & $.328^{* * *}$ & $.597^{* *}$ & $.272^{* * *}$ & $.312^{* * *}$ & 1 & $.766^{* * *}$ \\
\hline & Sig. (2-tailed) & .000 & .000 & .000 & .000 & & .000 \\
\hline MTC $(\mathrm{cm})$ & $\begin{array}{c}\text { Pearson } \\
\text { Correlation }\end{array}$ & $.418^{\text {*** }}$ & $.671^{\text {** }}$ & $.229^{* * *}$ & $.377^{* *}$ & $.766^{* * *}$ & 1 \\
\hline
\end{tabular}


Correlation is significant at the 0.01 level (2-tailed).

All of the included measurements were highly correlated with each other, with the best correlation coefficient observed between MAC and MTC (0.766) followed by Wt with MTC (0.671), then Wt with MAC (0.597), then Wt with OFC (0.491).

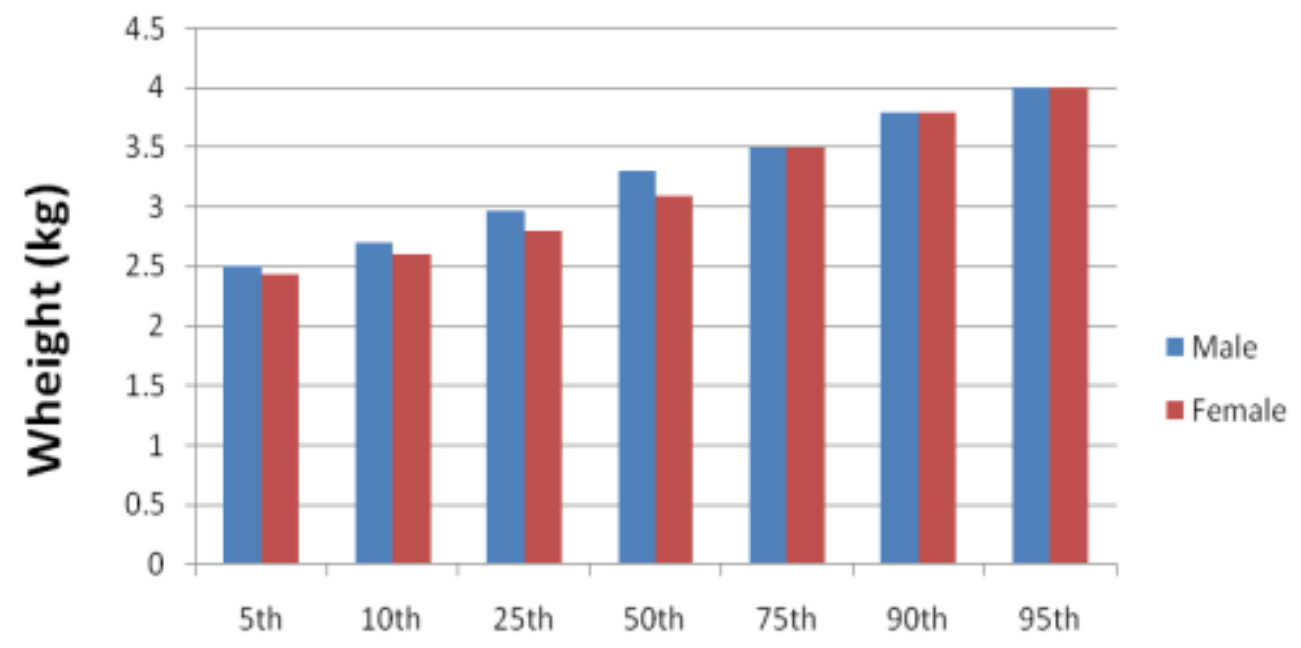

Percentile

Figure (3-1):-Weight percentile for males and females

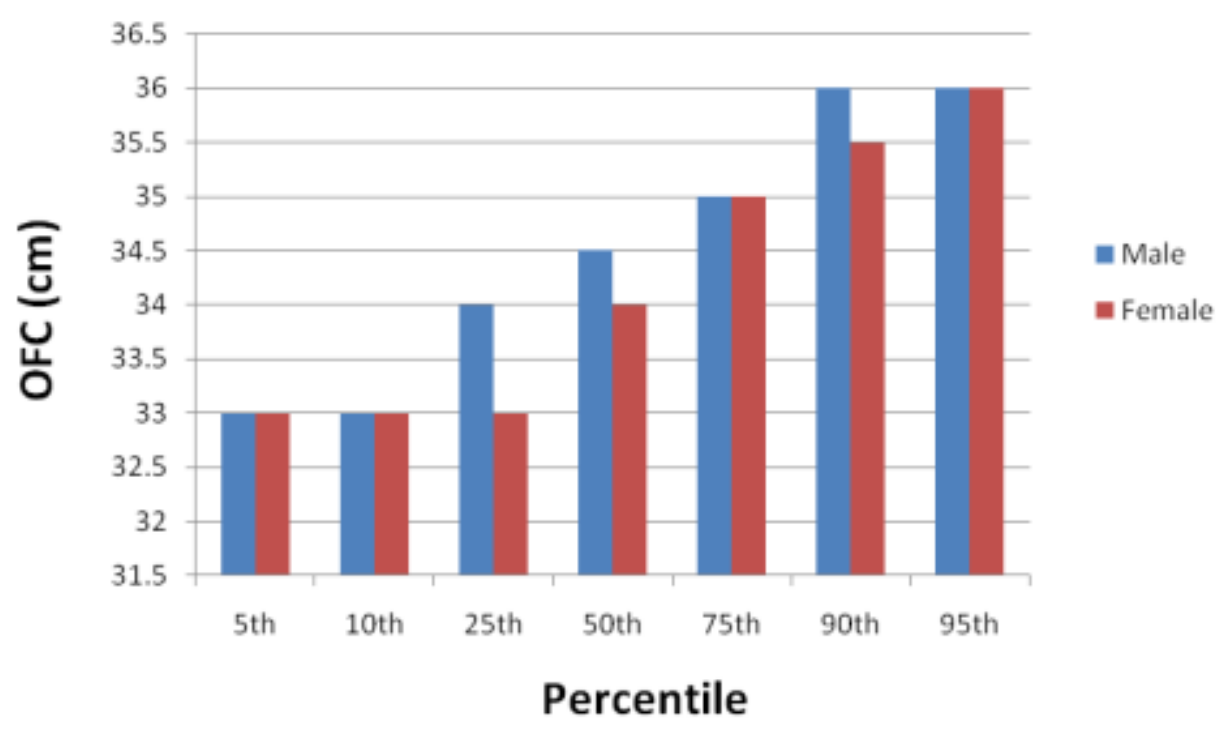

Figure (3-2):-OFC percentile for males and females 


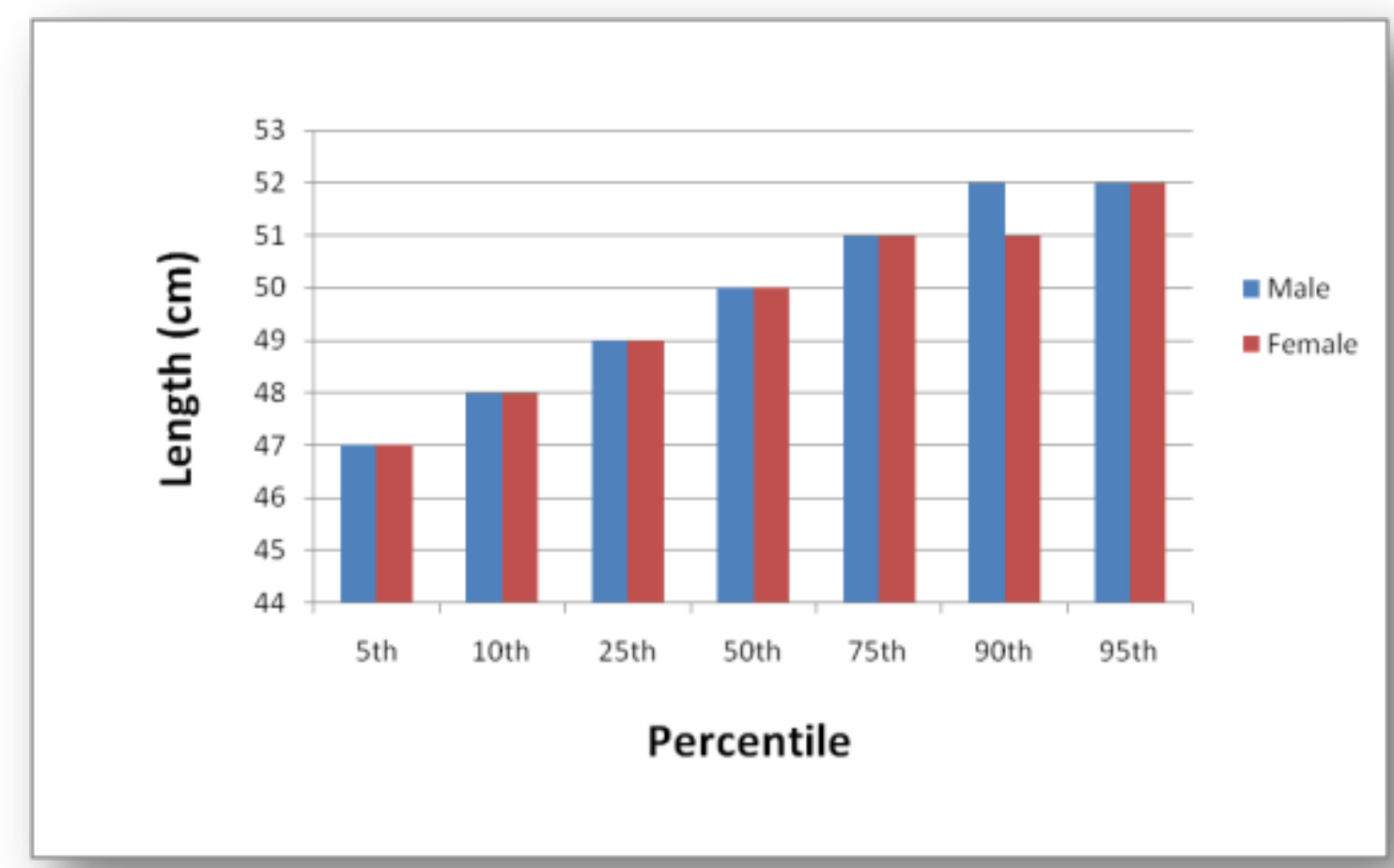

Figure (3-3):-Length percentile for males and females

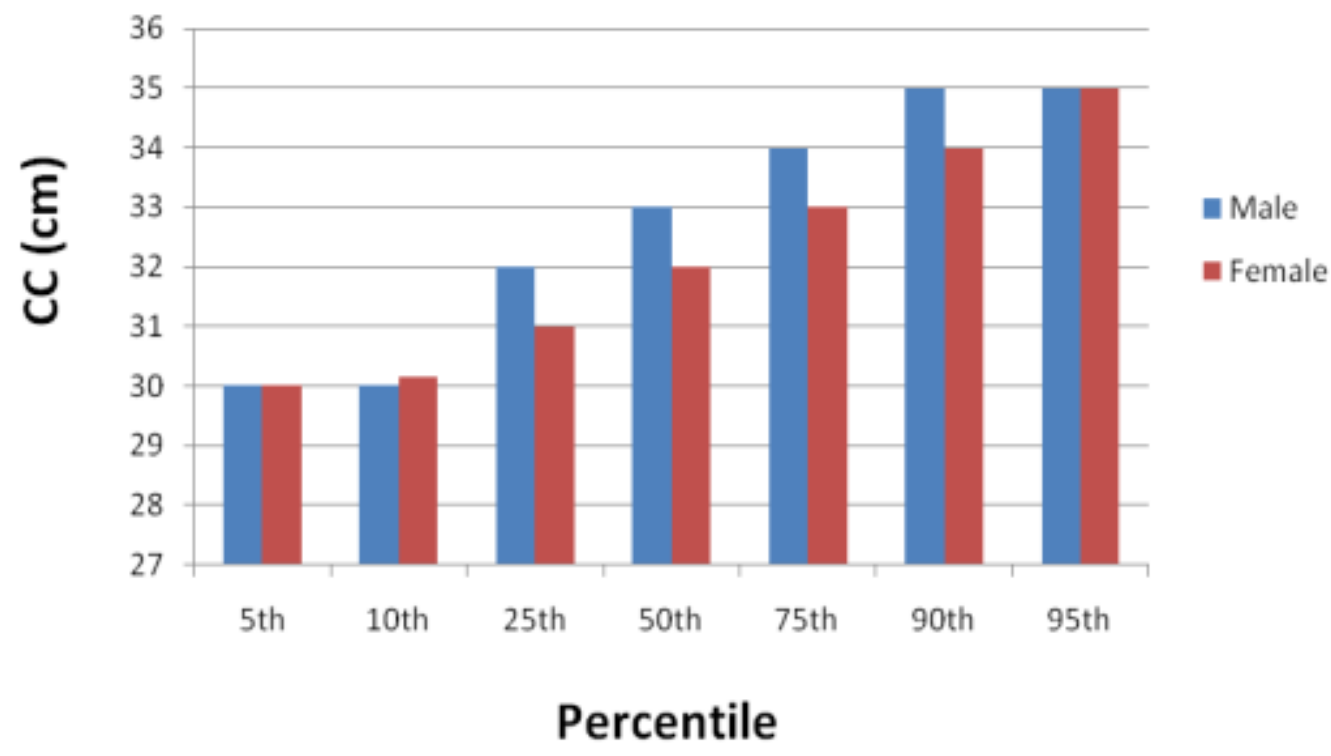

Figure (3-4):-CC percentile for males and females 


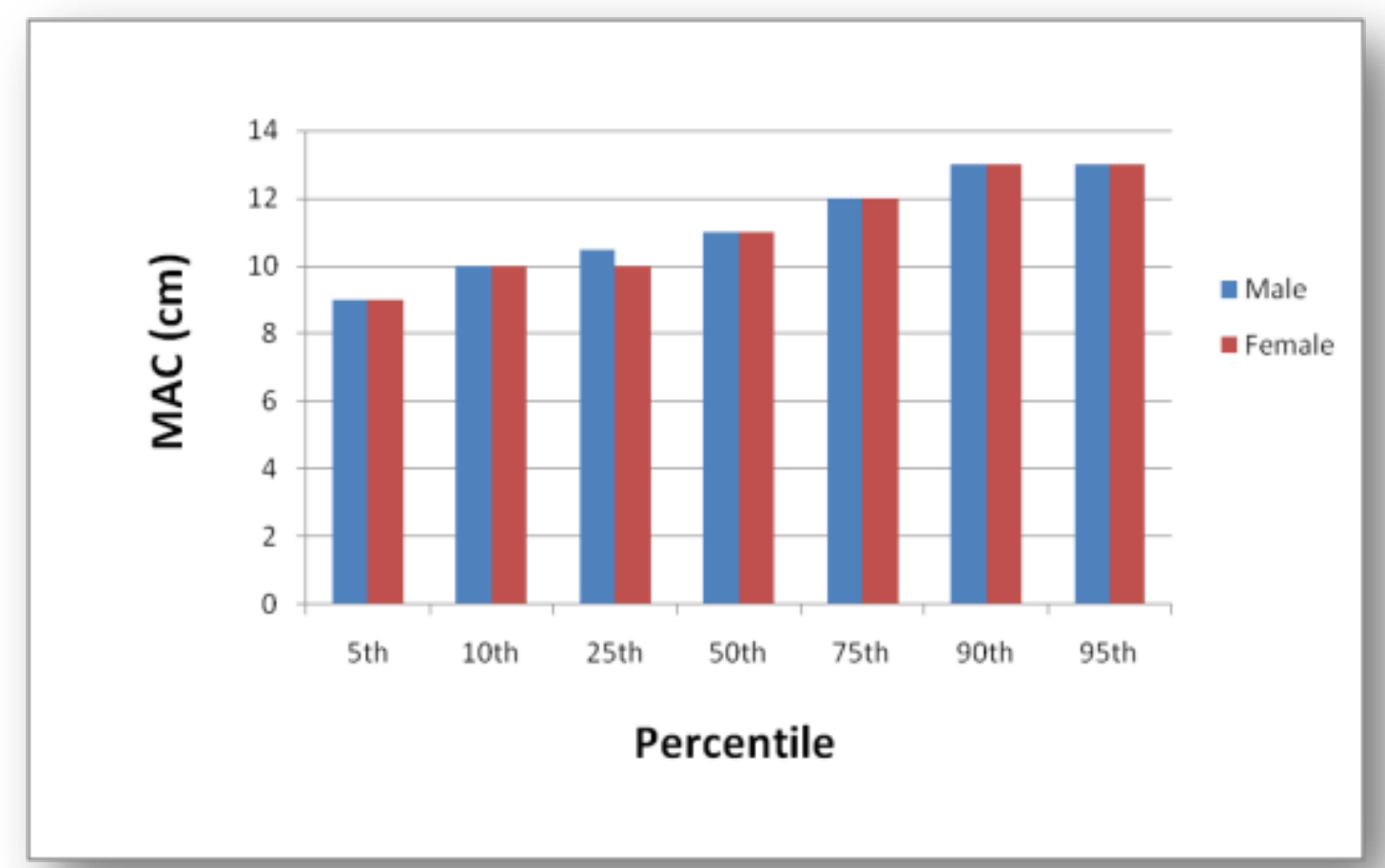

Figure (3-5):-MAC percentile for males and females

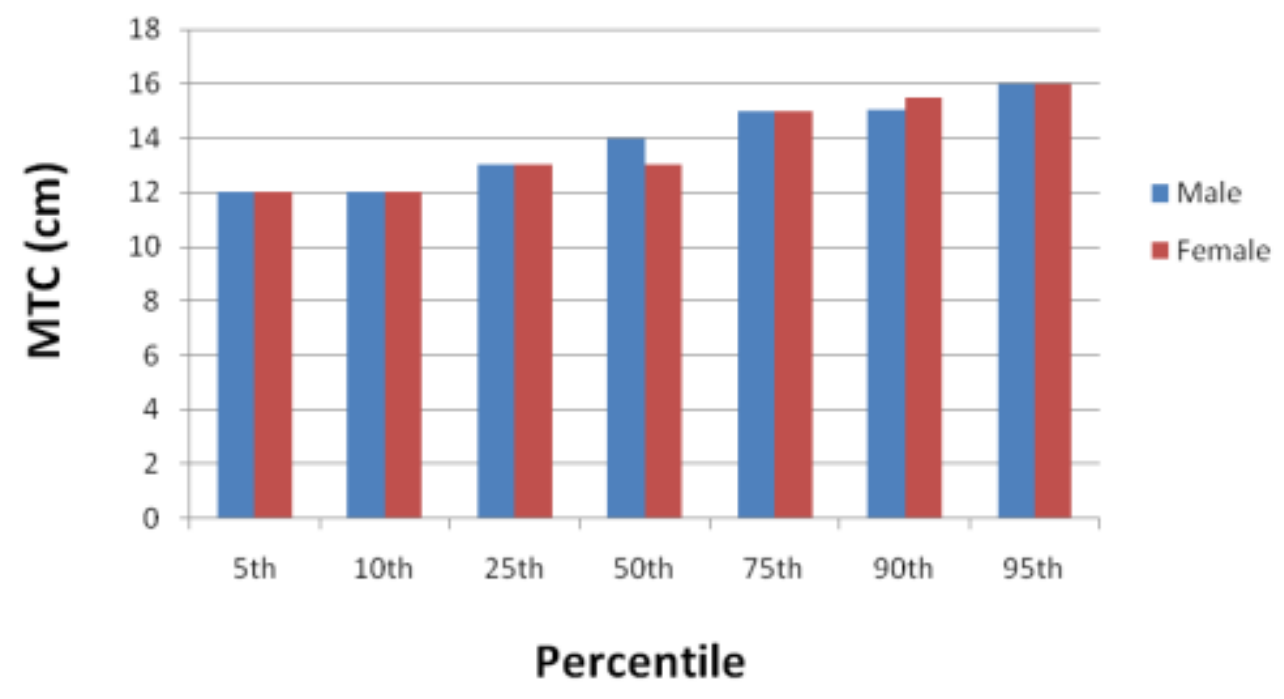

Figure (3-6):-MTC percentile for males and females 


\section{Discussion:-}

In the current study we tried to establish normal values for anthropometric measurements (Wt, L, OFC, CC, MAC and MTC) for 500 full term newborn in Najaf city. The mean birth (Wt, L and OFC ) were $(3.208 \mathrm{~kg}, 49.803 \mathrm{~cm}$ and $34.33 \mathrm{~cm}$ ) respectively, the Wt was significantly lower (p-value $<0.05)$ than NCHS mean $(3.274 \mathrm{~kg})^{[34]}$. Table (1) -page 10- shows the results regarding gender, the current study shows a significant difference ( $\mathrm{p}$-value $<0.05)$ in the measurement of CC only, where the males has higher $\mathrm{CC}$ than females, with a non-significant difference in other measurements. The OFC result $(34.429 \mathrm{~cm}$ for males and $34.228 \mathrm{~cm}$ for females) were in agreement with Telater et al. study in Istanbul $2009^{[56]}$, Nickavar et al. study in Tehran $2007^{[57]}$ and with Abdul-Hameed et al. study in AL-Yarmouk hospital-Baghdad 2002 ${ }^{[80]}$. The mean CC for males and females were 32.777 and $32.358 \mathrm{~cm}$, respectively. These results agree with previous studies ${ }^{[56,57]}$, where males CC was higher than that of females. The MAC was higher in males $(11.21 \mathrm{~cm})$ than in females $(11.18 \mathrm{~cm})$ and this result disagrees with Copper study in 1993 ${ }^{[58]}$ and with Calcutta study in $1991^{[59]}$. The MTC results $(13.79 \mathrm{~cm}$ for males and $13.64 \mathrm{~cm}$ for females)with no significant difference ( $\mathrm{p}$-value $>0.05$ ) and this result agrees with Huque study in $2007^{[54]}$. As shown in Table(2) -page11-, when we compared the mean values of the studied measurements according to residency of mothers, there was a highly significant difference in birth Wt (P-value < 0.001) which was higher among the newborns of urban mothers than those of rural and this is in agreement with other studies ${ }^{[60,61,62,63]}$. While, there was a significant difference in OFC ( $p$-value < 0.05) which was higher in newborns of rural mothers than those of urban. The Wt result may be related to maternal exhaustion as a cause for growth restriction in utero ${ }^{\text {[64] }}$, this agree with Phung et al. 2003 study in Europe ${ }^{[65]}$ but disagree with Nada et al. study in Mousl city 2008, and with other studies ${ }^{[66,67]}$. Regarding parity, as shown in table(3) -page 12- the products of a multipara had higher values of OFC with a highly significant difference ( $\mathrm{p}$-value $<0.001$ ), and significantly higher birth Wt ( $\mathrm{p}$-value $<0.05$ ), in general the other measurements were higher in newborns of multipara women than those of primipara women but with no significant statistical difference ( $\mathrm{p}$-value > 0.05). By comparing the results according to the mode of delivery (Table 4)-page 13- it was found that a slightly higher OFC, Wt, MAC and MTC in the newborns of mothers who delivered vaginally than those who delivered by caesarean section, this means that mothers may have an unexpected complication during their pregnancies and thus need delivery by caesarean section and this is in agreement with other study ${ }^{[60]}$. Table (5)-page 14- shows the studied measurements according to the regularity of ANC, it was clear that all measurements were higher in newborns with irregular ANC women, although the significant difference ( $\mathrm{p}$-value $<0.05$ ) only in Wt and OFC, this disagrees with Klerman et al. 2001; Isaksen et al. $1997^{[64,68]}$. Interpretation of growth parameters requires plotting the measurements on a percentile charts constructed from a similar race and environmental population. Table (6)-page 15- shows the percentiles of all the studied measurements in relation to gender, male OFC measurements were equal to the study of Al-Marzoki and Hussain 2010 In Hilla city ${ }^{[82]}$ in the 5th, 10th, 25th and 75th Percentiles, and equal to NCHS by AL-Shehri et al. 2005 and Telatar 2009 in Istanbul in the 10th Percentile. And to Abdul-Hameed et al. 2002 in Baghdad in the 50th percentile. Female OFC measurements were equal to Al-Marzoki and Hussain 2010 In Hilla in the 5th, 10th and 50th percentiles, and equal to NCHS in the 10th percentile and to Abdul-Hameed et al. 2002 in Baghdad in the 25th And 50th, and to Telatar 2009 in Istanbul in the 50th, 75th and 90th percentiles. Regarding the Wt, male Wt measurements were equal to th percentile NCHS in the 5th percentile and to Hilla study in the 25th, 90th, and 95th percentiles. Female Wt was equal to Hilla study in the 50th, 75th and 90th percentiles and to Baghdad study in the 75th and 95th percentiles. The male length measurements were similar to Hilla study in the 10th, 25th, 50th, 75th and 95th percentiles and to NCHS in the 50th percentile only. Female length measurements were similar to Hilla study in all percentiles and equal to NCHS in 75th percentile only. By comparing the current study results (Table 8) with other national and international studies, we found that:-

Table 8:-A comparison of anthropometric measurements(Wt, L, OFC and CC) of the current study with other studies done in Baghdad 2002, Tehran 2007 ${ }^{[57]}$, Istanbul $2009^{[56]}$ and NCHS standard values ${ }^{[79]}$ (except for CC in NCHS and Baghdad study because this measurement was not done).

\begin{tabular}{|c|c|c|c|c|c|c|}
\hline $\begin{array}{c}\text { Anthropometric } \\
\text { measurements }\end{array}$ & Gender & $\begin{array}{c}\text { Najaf } \\
(2010)\end{array}$ & $\begin{array}{c}\text { Baghdad } \\
(2002)\end{array}$ & $\begin{array}{c}\text { Tehran } \\
(2007)\end{array}$ & $\begin{array}{c}\text { Istanbul } \\
(2009)\end{array}$ & $\begin{array}{c}\text { NCHS } \\
(2007)\end{array}$ \\
\hline \multirow{2}{*}{ OFC(cm) } & male & 34.429 & 34.48 & 35.28 & 34.6 & 34.45 \\
\cline { 2 - 8 } & female & 34.228 & 34.11 & 34.78 & 34.1 & 34.17 \\
\hline \multirow{2}{*}{$W t(k g)$} & male & 3.256 & 3.143 & 3.285 & 3.387 & 3.309 \\
\cline { 2 - 8 } & female & 3.154 & 3.021 & 3.176 & 3.276 & 3.239 \\
\hline \multirow{2}{*}{$\mathrm{L}(\mathrm{cm})$} & male & 49.948 & 48.89 & 50.27 & 48.6 & 50 \\
\cline { 2 - 8 } & female & 49.636 & 48.29 & 49.51 & 47.9 & 49.62 \\
\hline
\end{tabular}




\begin{tabular}{|c|c|c|c|c|c|c|}
\hline $\mathrm{CC}(\mathrm{cm})$ & male & 32.777 & ---- & 33.55 & 32.9 & ---- \\
\hline \multicolumn{3}{|l|}{ LBW } & \multicolumn{4}{|c|}{ Low birth weight } \\
\hline \multicolumn{3}{|l|}{ IUGR } & \multicolumn{4}{|c|}{ Intrauterine growth restriction } \\
\hline \multicolumn{3}{|l|}{ WT } & \multicolumn{4}{|c|}{ Weight } \\
\hline \multicolumn{3}{|l|}{$\mathrm{L}$} & \multicolumn{4}{|l|}{ Length } \\
\hline \multicolumn{3}{|l|}{ OFC } & \multicolumn{4}{|c|}{ Occipitofrontal circumference } \\
\hline \multicolumn{3}{|l|}{$\mathrm{CC}$} & \multicolumn{4}{|c|}{ Chest circumference } \\
\hline \multicolumn{3}{|l|}{ MAC } & \multicolumn{4}{|c|}{ Mid arm circumference } \\
\hline \multicolumn{3}{|l|}{ MTC } & \multicolumn{4}{|c|}{ Mid thigh circumference } \\
\hline \multicolumn{3}{|l|}{ NCHS } & \multicolumn{4}{|c|}{ National Center For Health Statistics } \\
\hline \multicolumn{3}{|l|}{$\mathrm{CDC}$} & \multicolumn{4}{|c|}{ Center For Disease Control } \\
\hline \multicolumn{3}{|l|}{$\mathrm{Kg}$} & \multicolumn{4}{|c|}{ Kilogram } \\
\hline \multicolumn{3}{|l|}{$\mathrm{Cm}$} & \multicolumn{4}{|l|}{ Centimeter } \\
\hline \multicolumn{3}{|l|}{ ANC } & \multicolumn{4}{|c|}{ Antenatal care } \\
\hline \multicolumn{3}{|l|}{ VD } & \multicolumn{4}{|c|}{ Vaginal Delivery } \\
\hline \multicolumn{3}{|l|}{$\mathrm{CS}$} & \multicolumn{4}{|c|}{ Caesarean Section } \\
\hline \multicolumn{3}{|l|}{$p$-value } & \multicolumn{4}{|c|}{ Probability value } \\
\hline & female & 32.358 & \begin{tabular}{l|l} 
& --- \\
\end{tabular} & 33.13 & 32.6 & --- \\
\hline
\end{tabular}

\section{List of abbreviations}

The means of OFC were $34.429 \mathrm{~cm}$ and $34.228 \mathrm{~cm}$ for males and females respectively, with highly significant lower male and female values than Tehran study $(p$-value $<0.001)$, while significantly lower male values than Istanbul study results ( $\mathrm{p}$-value $<0.05$ ), with a non significant difference from other studies. The mean Wt of boys in the current study was $3.256 \mathrm{~kg}$ and it was of a highly significant difference from Baghdad and Istanbul studies (pvalue $<0.001$ ), where the current study result was higher than Baghdad result but lower than Istanbul study result, with a non significant difference from other studies. The mean Wt of girls in the current study was $3.154 \mathrm{~kg}$ and it was of a highly significant difference from Baghdad and Istanbul studies ( $\mathrm{p}$-value $<0.001$ ), where the current study result was higher than Baghdad result but lower than Istanbul study result, and significantly lower than NCHS study result ( $\mathrm{p}$-value < 0.05), and a non significant difference from other studies. The mean $\mathrm{L}$ of males was $49.948 \mathrm{~cm}$ in the current study and it was higher than Istanbul and lower than Tehran study with a highly significant difference ( $\mathrm{p}$ value $<0.001$ ), but higher than Baghdad study with a significant difference ( $p$-value $<0.05$ ), and a non significant difference from other studies. The mean $\mathrm{L}$ for females, it was $49.636 \mathrm{~cm}$ and it was higher than Baghdad and Istanbul study results with study with a highly significant difference ( $\mathrm{p}$-value $<0.001$ ), with a non significant difference from other studies. The mean CC of males was $32.777 \mathrm{~cm}$, which was lower than Tehran study with a highly significant difference ( $\mathrm{p}$-value $<0.001$ ), with a non significant difference from Istanbul study, while that of females was $32.358 \mathrm{~cm}$ which was lower than Tehran study with a highly significant difference $(\mathrm{p}$-value $<0.001)$, and lower than Istanbul study with a significant difference (p-value $<0.05)$. These results agree with multiple national and international studies including: AL-Mefraji. S.H study in AL-Kadhimya teaching hospital in Baghdad (2002-2004) which shows that most of measurements were less than standard references ${ }^{[70]}$. Many researchers have attempted to identify a suitable anthropometric surrogate to identify birth Wt which is reliable , simple and logistically feasible in field conditions. Some studies have recommended that CC, MAC and OFC may be used as anthropometric surrogate to identify birth $\mathrm{Wt}^{[72,73,74,75]}$, other studies recommended MTC $^{[76,77,78]}$,therefore we considered all the studied anthropometric measurements in a correlation coefficient matrix (Table 8)- page 18-. However in our study MTC followed by MAC and then CC were identified as a suitable anthropometric surrogate for birth Wt during the first day of life.

\section{Conclusion:-}

1. We tried to establish a normal values for anthropometric measurements (Wt, L, OFC, CC, MAC and MTC) for full term newborns in Najaf city, although higher sample number is recommended.

2. There are many factors having an effect on growth parameters, including gender, residence, parity, mode of delivery and ANC.

3. The current study in Najaf city shows a significantly lower birth weight than NCHS standard values and other studies carried out in neighboring countries but more than values in a study done in Baghdad at 2002. 
4. All of the included measurements were highly correlated with each other, with the best correlation coefficient observed between MAC and MTC followed by Wt with MTC, then Wt with MAC, then Wt with OFC.

\section{Recommendation:-}

1. The limitation of our study is that the percentile values we obtain reflect the result of only one hospital and a limited population, indicating that generalization to the Iraqi population cannot be made, so it is important to take samples from different governorates in our country with increasing the sample size so we can establish a standard anthropometric measurements for Iraqi neonates.

2. Further studies for follow up of the anthropometric measurements in different age groups of Iraqi children is recommended.

3. Growth parameters should be accurately measured by a doctor attending labour and each labour room should be provided with appropriate instruments for that.

4. Encourgment of regular antenatal care, mothers health support and nutrition to improve the fetal growth .

5. We can use mid-thigh circumference as a surrogate for birth Wt during the first day of life, which is simple and feasible in field conditions.

\section{Refrences:-}

1. Golden B,Reilly j.Nutrition.Anthropometric nutritional assessment.In: Mc-intosch N,Helms PJ,Symyth RL,Logan S.ForFar and Arneils Text book of Pediatrics,7th ed.Elsevier limited.2008;16:P.513-529.

2. Hamill PV, Drized TA, Johnson CL, Reed RB, Roche AF ,Moore WM.Physical Growth.National center for health statistics percentiles. American Journal of clinical nutrition.1979;32:607-629.

3. 3- Ronald EK.Assessment of nutritional status.Anthropometry.In:Ronald EK. pediatric nutrition handbook,5th ed.United states,American academy of paediatric. 2004;24:407-423.

4. Coutts J,Simpson JH andHeuchan AM.Fetal and neonatal medicine.assessment of the normal neonate.In:Beattie JandCarachi R.Practical paediatric problems. NewYork,Arnold press.2005;5:p.121-159 .

5. Sulkes SB,Dosa NP.Developmental and Behavioral Pediatrics.In:Behrman RE.Nelson Essentials of Pediatrics,4th ed.Philadelphia,WB Saunders.2002;1: P.1-56.

6. Johnston LB, Clark AJ,Savage MO.Genetic factors contributing to birth weight. ADC 2002; 86:2-3.

7. Galea P,Ali SR,Bhutta ZA.Neonatal paediatrics.Fetal and neonatal medicine. introduction. In:Goel KM,Gupta DK. Hutchisonś paediatrics,1st ed., Replika press Pvt.LTd. 2009;3:p.25-59 .

8. Neyzi O, Saka HN. Anthropometric studies in Turkish children. Istanbul Medical faculty Journal.2002;65:2218.

9. Alveor J,Brooke O.Fetal growth in different racial groups. Arch. Dis. Child. 1978;53:27-32.

10. Kelly AM, Snowdon DM and Weaver LT.Nutrition. Growth and nutrient accretion of fetus and infant.In: Beattie J and Carachi R. Practical paediatric proplem,New York ,Arnold press.2005;11:p.337-354.

11. Low L.Growth and development.assessment and monitoring of growth.In: Goel KM,Gupta DK.Hutchison's Paediatrics,1st ed,Replika press Pvt. LTd. 2009;2:p.16-24 .

12. Kuczmarski RJ, Ogden CL,Guoss,Grummer-Strawn LM, Flegal KM, Mei Z,Wei R,Curtin LR,Roche AF,Jognson CL.2000 CDC growth charts for the United State.methods and development. Vital Health State 11.2002 May;246:1-190.

13. WHO Multicentere Growth Reference study Group. WHO child Growth Standards.Acta Paediatr.Suppl.2006;450:76-85.

14. Garza C,Onis M.WHO Multicentre Growth Reference study Group. Rationale for developing a new international growth reference. Food Nutr Bull.2004;25:p.76-85.

15. WHO Multicentre Growth Reference study group.Enrollment and baseline characteristics in the WHO Multicentre Growth Reference study.Acta Paediatr Suppl.2006;450:7-15.

16. Needlman RD.Assessment of growth.In:Behrman RE,Kliegman RM,Jenson HB.Nelson Textbook of pediatric,16th ed.Philadelphia,WB Saunders. 2000;10: p. 57 -61.

17. 17-A growth chart for international use in maternal and child health care.guidlines for primary health care personnel.Genva, World Health organization, 1978.

18. 18-Bertagno JR,Mattos CA,Dal CG.Weight for length relationship at birth to predict neonatal diseases.Sao Paulo Med J.2003 Jul;121(4):149-154.

19. 19-Gomella.TL.Nutritional management. Growth assessment of the neonate. In:Gomella TL,Gunningham MD,Eyal FG and Zenk KE.Lange neonatology,5th ed.,MC Graw-Hill companies. 2004;8:p.77-101 . 
20. 20-Barbara JS.High risk pregnancies.In:Kliegman RM,Behrman RE,Jenson HB and Stanton BF.Nelson Text book of pediatrics, 18th ed. Philadelphia,WB Saunders.2007;95:p.683.

21. 21-Kleigman RM.Intrauterine growth restriction.In:Martin RJ,Fanaroff AA. Neonatal-perinatal medicine.8th ed.Philadelphia.Mosby.2006;p.271-306.

22. 22-Hobel C.Preterm labour and premature rupture of membranes.In: Hacker N, Moore G.Essentials Of Obstatrics And Gyneacology,3 rd ed.,Philadelphia, WB Saunders Company.1998:111-323.

23. 23-Graham W, Wagaarachchi P, Penney G, Binns A, Antwi K,Hall M. Criteria For Clinical Audit Of The Quality Of Hospital-Based Obstetric Care In developing Countries. Bull WHO.2000;78(5):614-620.

24. 24-Rafati S,Borna H,Akhavirad MB,Fallah N.Maternal determinants of giving birth to LBW neonates.Arch of Iranian Med.2005;8(4):277-281.

25. 25-Brenda Eskenazi, Gayle C, Windham, Shanna H, Swan AM. Obstet. and gynecol. survey.Public Health J.1997; 47(81):458 .

26. 26- Ashworth A .Effects of intrauterine growth retardation on mortality and morbidity in infants and young children. European Journal of Clinical Nutrition .1998; 52(1): 34-42.

27. 27- Mansour E,Eissa AN,Nofal LM,Kharboush I,Wagida A, Sallam I. Incidence and factors leading to LBW In Egypt.Int Pediatr J.2002; 17(4):223-230.

28. 28-Robert L. and Lorraine V.“Adolescent Pregnancy-Another Look".New England Journal of Medicine.1995;332(17):1161-62.

29. 29-Decherey AH, Nathan L. Current obstetric and gynecologic diagnosis and treatment. 9th ed. New York,MC Graw-Hill 2003:302-308.

30. 30-Lao TT. Obstetrics outcome of teenage pregnancies.The University of Hong Kong, Hum Reprod. 1998 Nov;13(11):3228-32.

31. Hansen JP.Older maternal age and pregnancy outcome.Obstetric Gyne J. 1986;41:7269.

32. 32- Sarah S. and Leon E.The Best Intentions: Unintended pregnancy and the wellbeing of children and families (Washington: National Academy Press, (1995).

33. 33- Sharon H and others."Association between Bacterial Vaginosis and Preterm Delivery of a low birth weight infant,”.New England Journal of Medicine.1995; 33(26):1737-42.

34. 34-Olsson J.The newborn.In: Kliegman RM, Behrman RE, Jenson HB, Stanton BF.Nelson textbook of pediatrics, 18th ed.Philadelphia,WB Saunder. 2007; $7: \mathrm{p} .41-43$.

35. 35-Cormic MC. The contribution of low birth weight to infant Mortality and morbidity. N Engl J Med.1985,312:82-90.

36. 36-Kumar V, Datta N, Birth Weight as an indicator of health .Indian Pediatric 1984;21:113-118.

37. 37-Warkany J, Monroe B, Satherland B S. intrauterine growth retadation. American J.Dis.Child.1961;102:249253.

38. 38- Andrew M, Virginia A. Pediatric nutrition and nutritional disorders. In : Behrman RE, Kliegman RM.Nelson Essentials of pediatrics, $14^{\text {th }}$ ed.Philadelphia ,WB Saunder.2002;2:p.57-92.

39. 39-Peile Ed.Growth.Differential growth in childhood.In:Bellman $\mathbf{M}$ and Peile Ed. The normal child, $1^{\text {st }}$ ed, Churchill livingstone elesevier.2006; 4: p.29-46.

40. 40-Kyle Th.The newborn. In: Kyle Th: Essentials of pediatric nursing.8th.ed. Lippincott Williams and Wilkins.2007;4:p.37.

41. 41-Athreya B H. Physical examination. In: Clinical Methods in Pediatric Diagnosis,5th.ed. Litton.1980;3:P.32-74.

42. 42-Patterson RM,Pouliot MR.Neonatal morphometrics and perinatal outcome. Am J Obstet Gynecol.1987;157(3);691-3.

43. 43- Patterson R M,Prihoda T J, Gibbs C E, Wood R C. Analysis of birth weight percentile as a predictor of perinatal outcome. Obstet Gynecol.1986;68(4):459-63.

44. 44-Fay R A, Dey P L, Saadie C M, Buhl J A,Gebski VJ.Ponderal index; a better definition of the "at risk" group with intrauterine growth problems than birth-weight for gestational age in term infants.Aust $\mathrm{N} Z \mathrm{~J}$ Obstet Gynecol.1991; 31 (1):17-9.

45. 45-Wales j k, Carney S, Gibson AT.The measurements of neonates.Horm Res. 1997;48(1):2-10.

46. 46-Pereira SL,Veiga GJ, Clington A, Videira JM, Bustamante SA. Upper arm measurements of healthy neonates comparing ultrasonography and anthropometric methods.Early Hum Dev.1999;54(2):117-28.

47. 47-Tanner J M.Growth as mirror of the condition of society. Secular trends and class distinction. Acta paediatrica japonica.1987;29:96-103.

48. 48-Reilly J.Nutrition.Anthropometric nutritional assessment.In:Campbell AG, Mcintosh N. Forfar and Arneils Textbook of pediatric, 5 th ed.Philadelphia, Churchill Livingstone.1998;p.1186-1187. 
49. 49-Das JC,Afroze A,Khanam ST,Paul N.Mid-arm circumference as an alternative measure for screening low birth weight babies.Bangladesh Med Res Counc Bull.2005;31:1-6.

50. 50-Dhar B,Mowlah G,Nahar S,Islam N.Birth weight status of newborns and its relationship with other anthropometric parameters in a public maternity hospital in Dhaka ,Bangladish.J Health popul Nutr.2002;20:3641.

51. 51-WHO.Use of a simple anthropometric measurement to predict birth weight. WHO collaborative study of birth weight surrogates. Bull World Health Organ. 1993;71:157-163.

52. 52-Prenatal care.in:Cunningham FG,Leveno KJ,Bloom SL,Hauth JC,Gilstrap LC,Wenstrom KD.Williams obstetrics,22nd ed.MC-Graw Hill companies. 2005; 8:p.201-229.

53. 53-Sreeramareddy CH,Chuni N,Patil R,Singh D,Shakya B.Anthropometric surrogates to identify low birth weight Nepalese newborns.A hospital based study.BMC Pediatr.2008;8:16.

54. 54-Huque FandHussain Z.Detection of low birth weight newborn babies anthropometric measurements in Bangladesh. Indian journal of pediatrics.2007 Nov; 58 (2):223-231 .

55. 55-Bettina B,MD .Mid-arm circumference and mid-arm /head circumference ratio in term newborns.Sao Paulo Med J.2004Apr;122(2):209-229.

56. 56-Telatar B., Comert S.,Vitrinel A and Erginoz E. .Anthropometric measurements of term neonates from a state hospital in Turkey.Eastren Mediterranean Health J.2009;15(6).

57. 57-Nickavar A, Golnar P. and Seddigh N. Determination of birth indices in healthy neonates. Acta Medica Iranica J.2007;45(6):469-472.

58. 58-Copper,Rachel L,Goldenberg,Robert L ,Cliver, Suzanne P,Dubard,Mary B, Hoffman,Howard J,Davis,Richard O. Anthropometric assessment of body size differences of full term male and female infants.American college of obstetricians and gynecologist.Obestet Gyne J.1993;81:161-4.

59. 59-Letter to the Editor,NRS Medical Colloge,Callcutta.Comparative usfulness of Arm,thigh and Calf Circumference for screening Low Brith weight infants. Journal of Tropical Pediatrics.1994October;Vol 40.

60. Kramer M Socioeconomic determinants of intrauterine growth retardation. European Journal of Clinical Nutrition. 2002; 52(1):29-33.

61. Prada J, Tsang R Biological mechanisms of environmentally induced causes in IUGR. European Journal of Clinical Nutrition. 1998; 52(1):21-28.

62. 62-Dejin-Karlsson,Hanson BS,Ostergren P,et al:Association of a lack of psychosocial resources and the risk of giving birth to small for gestational age infants:A stress hypothesis.Br.J.Obstet Gynaecol.2000;107:89.

63. 63- Idris MZ, Gupta A, Mohan U. Maternal Health And LBW Among Institutional Deliveries. Indian J Of Comm Med. (2002); 25(4) : 156-160.

64. 64-Klerman L, Rameys, Goldenberg, Marbury S, Hov J, Clivers. (2001) A Randomized Trial Of Augmented Prenatal Care. Amj Public Health 91(1) : 105 : 111.

65. 65- Phung H, Bauman A, Nguyen TV, Youngl, Tran M, Hillman K. Risk Factors For Low Birth Weight In A Socioecomically Disadvantaged Population. Parity, Marital Status, Ethinicity and Cigarette Smoking. Eur J Of Epidemiol 2003; 18(3) : 235-243.

66. 66-Pearlaman MD, Tintinall. JE, Lorenz RP. A Prospective Controlled Study Of Outcome After Truma During Pregnancy. Amj Obstet. Gynecol. 1990; 162:1502 Idris MZ, Gupta A, Mohan U. Maternal Health And LBW Among Institutional Deliveries. Indian J Of Comm Med. (2002); 25(4) : 156-160.

67. 67-Wannous S, Arous S. Incidence and determinats of LBW in Syrian Government Hospital. Emh j. 2001; 7(6) : 966-974.

68. Isaksen CV, Laurini RN; Jacobsen G.: Pregnancy risk factors of small for gestational age birth and perinatal mortality.1997;165: 44-9.

69. 69-Jaya DS,Kumar NS,Bai LS, Anthropometric Indices In Newborns. Indian Pediatric Journal,volume 32,November 1995.

70. 70-AL-Mefraji SH,AL-Tawil NG,Karim LA.Anthropometric measurement of a group of newborns.Saudi Medical Journal 2006,Jun;27(6):870-3.

71. 71-AL-Shehri MA,Abolfotouh MA,Dalak MA,et al.Birth anthropometric parameters in high and low altitude areas of South West Saudia Arabia.Saudi Med J. 2005 April,26(4):560-565.

72. 72-Mullany LC,Darmstadi GL,Coffey P,Khatry SK,LeClerq SC,Tielsch JM.A low cost, colour coded, hand held spring scale accurately categorises birth weight in low resource setting. Arch Dis Child 2006;91:410-13.

73. 73-GuptaV.Hatwal SK,Mathur S,Tripathi VN,Sharma SN,Saxena SC,Khadwal A.Calf circumference as predictor of low birth weight babies.India Pediatr. 1996;33;119-121.

74. 74- Ahmed F U, Karim E, Bhuiyan S N. Mid-arm circumference at birth as predictor of low birth weight and neonatal mortality.J Biosoc Sci.2000;32:487-493. 
75. 75-EzeakaVC.Egri-Okwaji MT,Renner JK,Grange AO.Anthroponetric measurements in the detection of low birth weight infant in Lagos.Niger Postgrad Med J.2003;10:168,172.

76. 76-Naik D B, KUlkarni A P, Answar N R. Birth weight and anthropometry of newborn. India J Pediatr.2003;70:145-6.

77. 77-Samal GC,Swain AK.Calf circumference as an alternative to birth weight to predict low birth weight babies.Indian Pediatr.2001;38:275-277.

78. 78-Arisoy AE,Sarman G. Chest and mid-arm circumferences: identification of low birth weight newborn in Turkey.J Trop Pediatr.1995;41(1):34-7.

79. 79-Susan FeigelmanThe second year.In:Kliegman RM,Behrman RE,Jensan HBandStanton BF(eds):Nelson Text book of pediatrics, $18^{\text {th }}$ ed.Philadelphia,WB Saunders;2007,9:P.48-54.

80. 80- Abdul-Hameed Gh. et al. 2002 ,(The Normal Anthropometric Measurements For Healthy Full Term Newborns in Baghdad City), a thesis submitted to the Iraqi board for medical specialization in pediatrics.

81. 81- Nada H. 2008 (The Normal Anthropometric Measurements of Newborns in Mousl City), a thesis submitted to the Iraqi scientific council for medical specializations in pediatrics.

82. 82- Al-Marzoki Jasim, Hussain Ashwaq 2010 (The Normal Anthropometric Measurements For Healthy Full Term Newborns in Hilla City), a thesis submitted to the Iraqi scientific council for medical specializations in pediatrics). 